\section{Entendendo o Processo Molecular da Tumorigênese}

\section{RESUMO}

Nos últimos 25 anos, o reconhecimento dos mecanismos genético-moleculares implicados na gênese e na progressão do câncer tem permitido obter novos métodos de diagnóstico e de acompanhamento, redirecionando de forma drástica a terapêutica do paciente com neoplasia. Alguns marcadores moleculares já estão sendo utilizados na rotina e deverão prover testes sensiveis e específicos para o diagnóstico precoce, estadiamento e acompanhamento do paciente com câncer. As características moleculares de cada tumor deverão permitir predição do seu comportamento, ajudando a delinear estratégias terapêuticas mais efetivas. Apresentamos de forma didática os principais mecanismos controladores do ciclo celular e do crescimento, definindo a importância de oncogenes erroneamente ativados e de genes supressores tumorais perdidos ou não-funcionantes, dos genes envolvidos na programação e manutenção da vida celular e de outros genes que atuam no processo de tumorigênese. Os mecanismos de progressão tumoral, invasão e metastatização à distância são revistos enfatizandose a aplicação prática do conhecimento a respeito de tais mecanismos. Lembramos o papel da instabilidade genética e dos fenômenos epigenéticos na definição fenotípica do câncer, sugerindo as aplicações da genética molecular na terapia gênica do câncer. (Arq Bras Endocrinol Metab 2002;46/4:351-360)

Descritores: Câncer; Ciclo celular; Genes; Molecular

\section{ABSTRACT}

\section{Understanding the Molecular Process of Tumorigenesis.}

Over the past 25 years, knowledge of the genetic-molecular mechanisms involved in the genesis and progression of cancer have helped to obtain new diagnostic and follow up methods that have drastically redirected the therapeutics used in patients with neoplasia. Some molecular markers are already being routinely used and should provide sensitive and specific tests for early diagnosis, staging and follow up of cancer patients. The molecular characteristics of each tumor should help in predicting its behavior and outlining more effective therapeutic strategies. We have used a didactic manner of presenting the main mechanisms that control the growth and cellular cycle, defined the importance of erroneously activated oncogenes and tumor suppressor genes that are lost or non-functioning, genes involved in programming and maintaining cell life as well as other genes that participate in the tumorigenic process. The mechanisms of tumor progression, invasion and metastasis are reviewed placing an emphasis on the practical application of the knowledge related to these mechanisms. The role of genetic instability and epigenetic changes in the definition of cancer phenotype have been underscored, suggesting the application of molecular genetics in the gene therapy of cancer. (Arq Bras Endocrinol Metab 2002;46/4:351-360)

Keywords: Cancer; Cell cycle; Genes; Molecular

\section{atualização}

\author{
Laura Sterian Ward
}

Laboratório de Genética Molecular do Câncer, Departamento de Clínica Médica, Faculdade de Ciências Médicas da UNICAMP, Campinas, SP.
Recebido em 14/05/2002 Aceito em 20/05/2002 
Como outras doenças CRÔNICAS, o câncer é um $\checkmark$ dos mais antigos males da humanidade. Estima-se que 10 milhões de casos novos tenham sido diagnosticados durante o ano 2000 em todo o mundo, cerca de 900 mil só nos EUA (1). Apesar de todo progresso que a compreensão dos mecanismos moleculares trouxe ao diagnóstico, à terapêutica e à prevenção da doença, em especial nos últimos 25 anos, a sobrevida do paciente com câncer pouco mudou. A cada ano, cerca de 400 mil americanos morrem de neoplasias diversas (1). No Brasil, o Ministério da Saúde registrou 114 óbitos por câncer para cada 100 mil habitantes em 1999 (2). Mais ainda, quando diagnosticados em fase de metástases, mesmo os tumores mais comuns, como os de origem epitelial, são difíceis de curar.

Entretanto, dados do National Cancer Institute mostram que as mortes por câncer de pulmão, cólon, mama, próstata e estômago têm diminuído cerca de $1 \%$ ao ano (3). Ao menos em parte, essa diminuição decorre do fato de que, durante as últimas décadas, temos compreendido melhor os mecanismos moleculares pelos quais danos genéticos, adquiridos ou herdados, conferem uma vantagem de crescimento a uma célula, a qual consegue transmitir às suas células filhas esta vantagem, dando origem a um clone de células que escapa dos controles normais de crescimento e diferenciação (4). Sabemos como ocorre o processo de transformação celular e o papel de diferentes genes na sucessão de eventos que se adicionam e se sobrepõem, levando a célula a tornar-se independente dos mecanismos controladores do ciclo celular. É este conhecimento que vem provendo a base para novas estratégias diagnósticas, proporcionando não apenas um diagnóstico mais precoce como a possibilidade de prever alguns tipos de tumores e de evitá-los. É este conhecimento que tem proporcionado delinear esquemas terapêuticos mais eficazes e seguros, traçando um perfil do comportamento do tumor. Finalmente, é este conhecimento que tem possibilitado a terapia gênica que, embora ainda embrionária, emerge como a esperança para a cura do câncer nos próximos anos.

\section{O CÂNCER COMO DOENÇA AMBIENTAL}

Embora o risco de desenvolver alguns poucos tipos de neoplasia tenha diminuído, a prevalência das formas mais significantes de câncer se tornou nitidamente mais elevada em todos os países que se industrializaram nas últimas décadas. Cânceres como de pulmão, mama, próstata e colo têm se tornado mais fre- qüentes em países onde existem fatores de risco como o fumo, hábitos alimentares pouco saudáveis e exposição a produtos químicos e agentes físicos carcinogênicos no trabalho ou no meio ambiente. Estudos epidemiológicos apontam o fumo como o principal carcinógeno (5). O cigarro causa câncer de pulmão, de vias aéreas superiores, de esôfago, de bexiga e de pâncreas. Provavelmente também está implicado no câncer de estômago, fígado e rim, na leucemia mielóide e no câncer de cólon (5). Hábitos alimentares modernos, particularmente a elevada ingestão de gordura saturada e a baixa ingestão de fibras têm sido fortemente relacionados com o câncer de cólon. A obesidade aumenta o risco de câncer de endométrio e, por razões ainda pouco claras, do câncer de cólon, rim e vesícula. O consumo de álcool predispõe ao câncer do trato digestivo e do trato respiratório, e a cirrose alcoólica pode levar ao câncer de fígado. Várias formas de irradiação também têm sido implicadas na gênese de diversos tipos de câncer. Existem indubitáveis evidências de que a radiação ionizante produz câncer da tiróide e de que a radiação ultravioleta predispõe ao câncer de pele e se relaciona de forma clara com o melanoma maligno. Além dos agentes físicos e químicos, agentes biológicos têm sido reconhecidos como importantes desencadeadores do processo de tumorigênese. $\mathrm{O}$ papilomavírus tem sido identificado em 18 a 95\% dos carcinomas de colo uterino e, embora a infecção viral sozinha não seja suficiente para iniciar o processo de transformação maligna do epitélio cervical, numerosas evidências indicam que a presença do vírus predispõe a alterações genéticas adicionais $(6,7)$. Outros vírus possuem estreita relação com tumores, como os vírus da Hepatite B e C com o câncer hepático, o Epstein-Barr com o linfoma de Burkitt, o HTLV-1 com a leucemia de células T (8).

\section{GENES DE PREDISPOSIÇÃO AO CÂNCER}

Como é que as agressões ambientais, químicas, físicas e biológicas causam danos às nossas células? Uma grande parte de conhecidos agentes carcinogênicos sofre uma bio-transformação para compostos que são convertidos em metabólitos não-tóxicos que podem ser excretados facilmente pelo organismo humano. A eficácia das vias metabólicas que atuam neste processo de detoxificação pode, portanto, determinar o dano inicial causado por um determinado carcinógeno ao 
DNA e, subseqüentemente, o risco de desenvolvimento de neoplasia. Entre as diferentes enzimas envolvidas no metabolismo de carcinógenos químicos, tem-se dado particular importância ao sistema da Glutationa Transferase (GST). O sistema é formado por um conjunto de enzimas de desintoxicação conhecido pela sua herança polimórfica na população geral. Existem evidências de que os genótipos nulos para GSTMI e GSTTl aumentam a susceptibilidade para vários cânceres como de cólon, mama, bexiga, cabeça e pescoço. Comparando a prevalência da herança de tal polimorfismo em 116 pacientes com tiroidopatias (49 bócios multinodulares e 76 carcinomas bem diferenciados da tiróide) com a de 300 indivíduos moradores em nossa região de Campinas, encontramos uma prevalência maior do genótipo nulo nos portadores de câncer (9). A herança nula para ambos os alelos teta e mu representa um risco relativo 2,5 vezes maior para câncer de tiróide nos portadores de tal genótipo (9). Outros genes também podem predispor ao câncer por tornarem o genoma instável, conceito que será abordado mais adiante; por levarem a uma ativação constitutiva de vias sinalizadoras de crescimento às células afetadas; por dificultarem ou impedirem o reconhecimento e/ou adequado reparo de lesões causadas pelos agressores ambientais ao nosso genoma ou por permitirem prolongamento do tempo de vida celular normalmente programado.

Exemplos de anormalidades gênicas predispondo ao câncer são encontrados nas síndromes genéticas caracterizadas por mutações hereditárias. As formas hereditárias de câncer são modelos únicos na pesquisa básica em câncer. Em famílias afetadas, a localização de gene responsável pode ser feita por análise de ligação. Uma vez localizado e isolado, este gene pode ser estudado para mutações. Uma grande parte dos genes causadores de neoplasias hereditárias está envolvida também no desenvolvimento de neoplasias esporádicas. Assim, a investigação de várias formas esporádicas de câncer começou com a identificação dos defeitos genéticos nas síndromes familiares correspondentes. Em um determinado paciente, a distinção entre formas esporádicas e familiares de câncer pode ser realizada em amostras de sangue para verificação de mutações chamadas de germinativas, que existem em todas as células de seu organismo, ou apenas nas células do tecido anormal que adquiram a mutação, chamada neste último caso de somática.

Em famílias com predisposição ao câncer, a identificação do gene defeituoso permite o diagnóstico pré-clínico e o tratamento profilático. A expectativa e a qualidade de vida destes doentes podem, assim, ser consideravelmente alteradas. Um claro exemplo disto é o gene ret. A identificação de mutações em $95 \%$ dos portadores da forma hereditária e $15-25 \%$ dos carcinomas medulares de tiróide esporádicos tornou possível o desenvolvimento de testes de rastreamento precoce capazes de identificar indivíduos de risco para síndrome da neoplasia endócrina múltipla (NEM) (10). Alguns dos genes implicados em hiperfunção hereditária de uma glândula endócrina estão também implicados em neoplasias endócrinas esporádicas. Por exemplo, o gene do receptor do hormônio tireotrófico (TSH-R) está implicado na gênese de tumores hiperfuncionantes da tiróide, os adenomas tóxicos, e o gene receptor de hormônio luteotrófico (LH-R) estão implicados em adenomas de células de Leydig $(11,12)$. Também grande parte dos genes envolvidos em diversas neoplasias esporádicas foi descoberta a partir de síndromes familiares, como o gene $B R C A I$ no câncer de mama, o próprio gene p53, causador da síndrome de Li Fraumeni, o gene ret em carcinoma medular etc. Mais recentemente, demonstrou-se que uma mutação germinativa de p53 está implicada no câncer de adrenal da população do sudeste do Brasil $(13,14)$.

É interessante notar que, embora os genes de câncer herdados estejam geralmente expressos em praticamente todos os tecidos, os portadores destas mutações germinativas apresentam tumores restritos a apenas alguns tecidos. Assim, mutações do gene $R B I$ predispõem ao retinoblastoma e ao osteossarcoma, mais raramente ao melanoma e a outros sarcomas. Mutações germinativas de p53 predispõem ao osteossarcoma, sarcomas de partes moles, tumores cerebrais, leucemias e câncer de mama em mulheres enquanto que mutações de $\mathrm{pl} 6$ predispõem ao melanoma maligno e ao câncer de pâncreas (15). Acredita-se que variações alélicas e a presença de genes modificadores contribuam para que mutações herdadas em genes potencialmente carcinogênicos apresentem estes espectros diferentes de fenótipos no ser humano (15).

\section{O CICLO CELULAR - ONCOGENES E GENES SUPRESSORES TUMORAIS}

O câncer é uma doença genética no sentido de que o fenótipo maligno resulta de uma alteração genética que é transmitida da célula alterada para suas células filhas. Todos os dias, milhões de células se dividem no organismo adulto normal. A cada divisão celular, estamos expostos a sofrer o efeito dos inúmeros carcinógenos ambientais. No entanto, o aparecimento e desenvolvimento de um clone de células tumorais é 
um evento relativamente raro. Isto ocorre porque a célula necessita romper uma série de barreiras fisiológicas para se tornar cancerígena. As barreiras mais primárias são os próprios pontos de controle do próprio ciclo celular. Na figura 1 , esquematizamos alguns destes pontos de controle.

Esta seqüência de fases, com seus respectivos pontos de controle, permite que a célula complete seu ciclo normal, replicando-se sem dar origem a células anormais. A divisão celular normal é positivamente regulada ou estimulada através de vias sinalizadoras. Estas vias respondem a fatores extracelulares, os quais agem através de uma seqüência de proteínas - por exemplo: receptores $\rightarrow$ proteína $\mathrm{G} \rightarrow$ proteíno-quinases $\rightarrow$ fatores de transcrição. A progressão pelo ciclo celular a seguir é, em parte, controlada, por uma série de proteínas chamadas "quinases dependentes de ciclinas" (CDKs), particularmente nas transições de fases, tanto de Gl para S quanto de G2 para M (16). Os níveis de ciclinas oscilam durante as fases do ciclo, determinando o momento apropriado de sua ligação

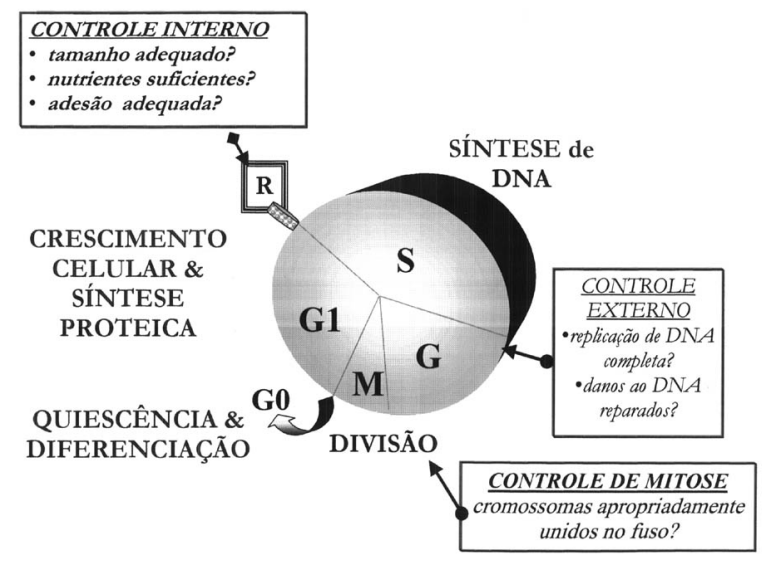

Figura 1. Pontos de controle do ciclo celular. O ciclo celular é composto de uma seqüência ordenada de fases. A célula diferenciada se encontra em $\mathrm{G}$, onde ela atingiu sua diferenciação terminal e está quiescente. Se a célula está destinada a proliferar, ela entra em Gl, período em que aumenta de tamanho e prepara as proteínas de que necessita para a síntese de DNA. Durante esta fase, a célula é sensivel às condições ambientais. Se elas não forem favoráveis, a divisão celular pára em Gl. No entanto, se ultrapassar o ponto $\mathrm{R}$ (ponto de restrição), a divisão celular ocorrerá independente de condições ambientais. Na fase $S$ sintetiza-se o DNA que será replicado durante a fase $G 2$. No início de $G 2$ existe outro ponto de controle importante, onde se verificará a qualidade do DNA replicado. Finalmente, na fase mitótica (M), o DNA duplicado será eqüitativamente dividido entre as duas células filhas. A mitose será impedida se, na checagem da mitose, forem constatadas anormalidades na divisão dos cromossomas. com CDKs. Este grupo de enzimas, por sua vez, fosforila uma série de substratos-chave que permitirão a progressão de uma fase a outra do ciclo celular, como exemplificamos através de esquema na figura 2 (16). Por outro lado, um grupo de inibidores do ciclo atuam impedindo ou regulando negativamente as vias sinalizadoras de tal progressão no ciclo de divisão celular. À semelhança dos fatores estimuladores que levam à produção de ciclinas/CDKs, os reguladores negativos ativarão inibidores dos CDKs: os CDKIs. Podemos distinguir duas famílias de CDKIs, de acordo com seu mecanismo de ação, homologia e CDK alvo: 1) o grupo do p21, p27 e p57 e 2) o grupo do pl6, p15, p18 e p19 (16). Este circuito de indutores e de bloqueadores do ciclo celular está representado na figura 3 .

Anormalidades tanto nos genes estimuladores de divisão celular (chamados de oncogenes), como nos protetores ou bloqueadores do ciclo celular (chamados de genes supressores tumorais), podem conferir a uma célula vantagens de crescimento e desenvolvimento sobre as células normais. Cada uma das proteínas envolvidas no ciclo celular é codificada por um gene. Mutações nestes genes podem levar à desregulação do ciclo celular. Os genes que atuam de forma positiva, induzindo ou estimulando a progressão do ciclo, são chamados proto-oncogenes pois ao sofrerem mutações se tornarão oncogenes, cuja ação permitirá ganho de função à célula mutante. Ao contrário, as proteínas envolvidas no controle negativo do ciclo celular são codificadas pelos assim chamados genes supressores tumorais. Mutações neste grupo de genes se manifestarão pela sua falta de ação mas o efeito final será similar: perda dos mecanismos controladores do ciclo celular normal (17). Já se sabe há muito tempo que

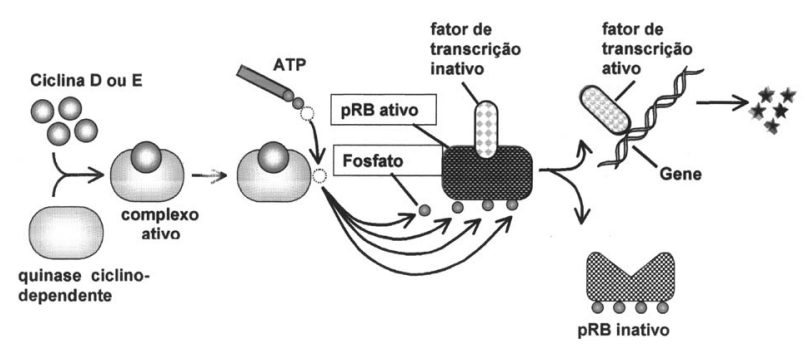

Figura 2. Mecanismo de controle do avanço do ciclo celular. A associação das ciclinas $\mathrm{D}$ ou $\mathrm{E}$ com suas respectivas quinases formam um complexo ativo que, por sua vez, promove a fosforilação da proteína $\mathrm{Rb}$. Uma vez fosforilada, Rb libera um complexo fator de transcrição chamado E2FDP1. Ao ser ativado, este fator, por sua vez, promove a transcrição de genes que serão importantes na fase de síntese (S) para produzir nucleotídeos e enzimas necessárias para a replicação do material genético.

Arq Bras Endocrinol Metab vol $46 n^{\circ} 4$ Agosto 2002 


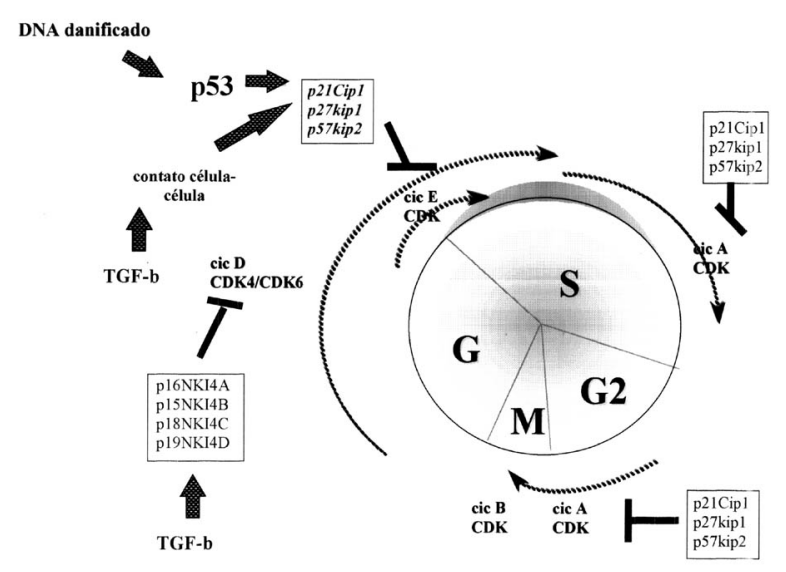

Figura 3. Fatores de estímulo e bloqueio do ciclo celular. As ciclinas são reguladoras das sub-unidades das CDKs. Diferentes ciclinas se associam a diferentes CDKs, podendo associar-se a mais de uma CDK nas diferentes fases do ciclo celular. A atividade ciclina/CDK é bloqueada por uma série de inibidores específicos. Eles podem ser agrupados em famílias como a do p21/p27/p57, que bloqueia múltiplos complexos ciclina/CDKs e na família p16/p15/p18/p19, que inibe os complexos CDK4/CDK6. Alguns fatores podem parar o ciclo em G1, como os danos causados ao DNA que, ativando o p53, induzem a produção de p21. Outros fatores podem atuar através de diferentes grupos de inibidores do ciclo, como TGF-b que induz produção tanto de p15 como de p27.

expressão imprópria de fatores de crescimento ou de seus receptores contribui para o desenvolvimento de neoplasias. Mais recentemente, demonstrou-se que hiper-expressão da ciclina Dl induz progressão de hiperplasia a carcinomas em camundongos (16). Amplificações da ciclina Dl também foram encontradas em tumores primários e linhagens celulares tumorais (16). No ser humano, medidas indiretas baseadas na prevalência de tumores em diferentes faixas etárias, permitem inferir que são necessárias cerca de cinco a seis mutações sucessivas para que uma célula se torne maligna e agressiva (18).

As mutações envolvendo oncogenes são mutações ativantes e podem ocorrer por uma série de mecanismos: translocação cromossômica, amplificação gênica, inserção retroviral, mutação pontual (17). Os produtos resultantes da ativação destes genes atuam de forma dominante, isto é, a mutação de um único alelo poderá ser suficiente para conferir à célula uma vantagem em termos de crescimento ou transformação, levando à neoplasia em uma série de tecidos humanos. A primeira identificação de tal ação oncogênica foi na leucemia mielóide crônica (LMC) onde Nowell e cols. mostraram que uma translocação 9:22 faz com que se forme um gene fundido bcr-abl e uma proteína, uma tirosino-quinase, cuja função fosforiladora contribui para a sobrevida e o fenótipo neoplásico das células da LMC (18).

Os genes supressores tumorais, ao contrário, agem inibindo ou prevenindo a expressão do fenó- tipo maligno. Assim, os genes supressores tumorais atuam de forma recessiva, isto é, ambos os alelos devem estar perdidos ou não-funcionantes (19). O exemplo clássico do gene supressor tumoral é o gene defeituoso herdado no retinoblastoma familiar. Da observação de famílias portadoras de retinoblastoma, Knudson desenvolveu uma explicação para a ocorrência de tumores familiares que se tornou um paradigma na compreensão do câncer (20). Mesmo quando não se herdou um dos alelos do gene $R b$ ou se herdou um alelo não-funcionante, o alelo normal restante do gene supressor tumoral é suficiente para proteger o organismo do desenvolvimento de um câncer. Este só se manifestará por perda ou inativação deste alelo normal, ocorrência eventual durante a proliferação celular, particularmente porque a herança deste alelo anômalo causa instabilidade do genoma ou induz fenômenos epigenéticos, como veremos mais adiante (20). Esta é a base da teoria dos 2 golpes de Knudson: um primeiro golpe seria a herança do gene supressor defeituoso ou perdido e um segundo golpe envolveria a perda do segundo alelo levando à formação do câncer.

Os GST são os mais freqüentemente mutados na maior parte das neoplasias humanas, com a notável exceção dos cânceres de linhagem hematológica. Os exemplos mais conhecidos de genes supressores tumorais são os genes p53 e Rb que exercem um estreito controle interligado da divisão celular, como demonstramos na figura 4 . 

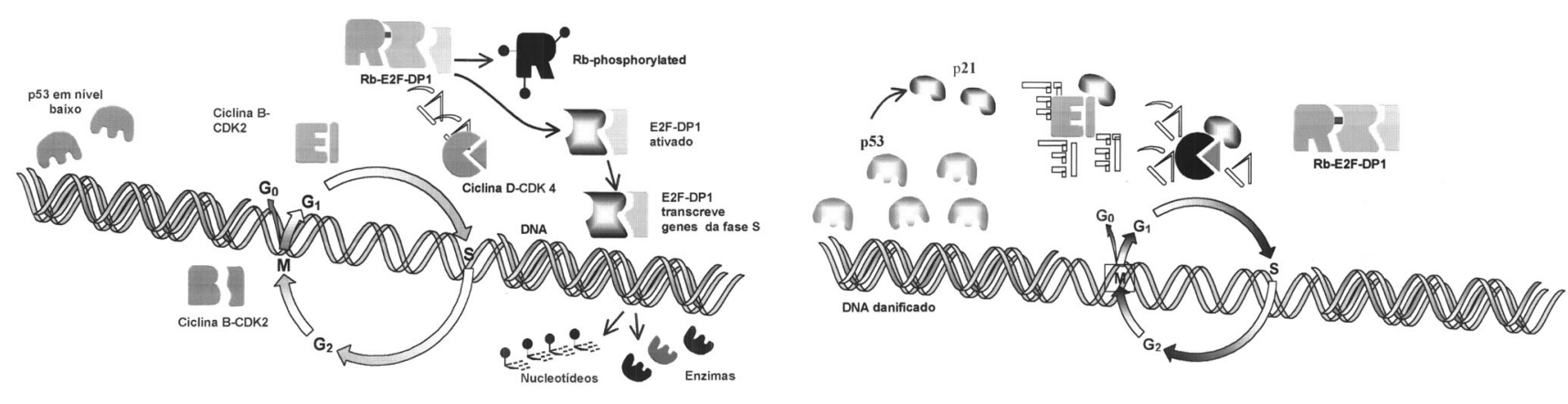

Figura 4. Parada do ciclo celular para reparo de danos ao DNA. O painel A mostra o ciclo celular prosseguindo normalmente sob a vigilância passiva de p53 cujos níveis se mantém baixos. No painel B, mostramos como, detectando um dano ao material genético, imediatamente os níveis de p53 se elevam, induzindo expressão de p21 e de uma série de outros produtos gênicos que impedirão a ligação ciclina-CDK. Conseqüentemente, Rb não será fosforilada, impedindo assim a liberação do fator de transcrição formado pelo complexo E2F-DPI que não poderá ativar os genes essenciais para a progressão na fase S. Com isso, a célula pára no ciclo de divisão celular permitindo o reparo adequado do material danificado.

\section{GENES CONTROLADORES DO TEMPO DE VIDA CELULAR}

Os genes que controlam o tempo de vida ou programam a morte celular, como o gene da telomerase, os genes envolvidos no processo da apoptose e os genes de reparo do DNA também intervém diretamente no processo de tumorigênese. Quanto mais tempo uma célula viver, maior será sua chance de adquirir mutações vantajosas em termos de crescimento e diferenciação. Sabemos que todas as células carregam programas de controle de seu tempo de vida. Entre estes mecanismos, o da apoptose provê rápida eliminação de células desnecessárias ou perigosas ao organismo. Assim, durante o desenvolvimento, o tamanho dos órgãos é regulado, em parte, pelo rígido controle do número de células de cada tecido, eliminando-se células excessivas por apoptose. É por esse mecanismo que eliminamos a hemoglobina fetal após o nascimento. Outro exemplo importante é a eliminação pelo timo de muitas células $T$ que têm potencial autoimune. Muitos tumores sobrevivem e se desenvolvem graças a mecanismos moleculares que lhes permitem resistir ao comando para entrar em apoptose (21). O gene bcl2 é um exemplo de gene que, ao permitir prolongamento da vida da célula, faz com que ela tenha mais oportunidade para adquirir novas mutações vantajosas. O produto de $b c l 2$ interage fisicamente com uma ou mais proteínas estruturalmente relacionadas (como Bax) que promovem atividade apoptótica. As anormalidades moleculares que impedem a apoptose de algumas células tumorais humanas resultam de defeitos em via de sinaliza- ção/transdução (22). Os componentes desta via, inicialmente demonstrados por Horvitz em estudos com nemátodes, foram preservados evolutivamente apontando para sua importância no desenvolvimento orgânico (22).

Outro gene que merece destaque no grupo dos determinantes do tempo de vida e da morte celular é o gene da telomerase. Este gene codifica a produção de uma enzima responsável pela produção da seqüência repetitiva de nucleotídeos que recobre os telômeros, isto é, as extremidades distais do cromossoma. A cada replicação cromossômica, os telômeros são consumidos de forma e, a não ser que eles sejam recompostos por ativação da telomerase, após determinado número de divisões celulares a célula não consegue mais se replicar. Cooke, em 1986, sugeriu que o desgaste do DNA telomérico poderia explicar um programa de vida mais curta em algumas células, como as hemácias (23). Surgiu assim a idéia de que o gene da telomerase seria um relógio biológico celular. A perda telomérica, por outro lado, protegeria as células humanas de se tornarem tumorais e darem origem a linhagens imortais. Realmente, imortalização de células humanas em cultura se acompanha invariavelmente de ativação da telomerase ou de outro mecanismo pelo qual os telômeros são protegidos (24). Uma função telomérica normal protege o cromossoma permitindo reparo de eventuais danos e estabilizando o genoma (25). Entretanto, a telomerase não está ativada em muitos tipos de câncer enquanto que, em outros, parece ser apenas parte de uma constelação maior de outros genes afetados, como o $B R C A-1$ e o $R b(25)$. 


\section{GENES Envolvidos na Progressão e Metastatização à Distância}

Para que um tumor progrida, uma série de genes, afora os que iniciaram o processo de transformação celular, devem se alterar. Sabemos que o processo de metástase é seletivo para as poucas células que conseguem produzir vasos (angiogênese), já que, após atingirem um certo tamanho, os tumores não mais podem sobreviver por simples adsorção de nutrientes do parênquima adjacente. As células tumorais devem se mover vencendo barreiras e invadindo as células vizinhas, tecidos, cápsulas etc. Para isto necessitam destacar-se das outras células, perdendo portanto sua adesão que, durante a fase do crescimento tumoral, era essencial para prover sobrevivência e proliferação. Uma vez capazes de atravessar paredes como a dos vasos, as células tumorais deverão embolizar e sobreviver na corrente sangüínea, onde estarão vulneráveis ao ataque de uma série de mecanismos imunológicos de reconhecimento e eliminação. Se conseguirem realizar tal façanha, estas células ainda terão de parar em leitos capilares distantes, extravasar e se multiplicar dentro do parênquima de outros órgãos. Todos estes passos requerem produtos originários de ativação e/ou desativação de uma série de genes. Alguns cânceres produzem fatores químicos que atraem plaquetas, as quais aderem ao seu redor e as escondem do sistema imunológico, além de prover um rico suprimento de fatores de crescimento que ajudarão na sobrevida da célula tumoral em circulação. A circulação sangüínea explica em grande parte porque metástases ocorrem preferencialmente em determinados tecidos. As células tumorais que atingem o leito vascular geralmente seguem o fluxo que, primariamente, levará aos pulmões; somente os intestinos mandam seu fluxo sangüíneo primeiro para o fígado que é, após os pulmões, o órgão mais freqüentemente acometido por metástases. Entretanto, algumas células cancerígenas preferem determinados tecidos para se alojar, como por exemplo o câncer de próstata que metastatiza para osso. Estas células cancerígenas devem possuir moléculas de adesão à parede interna dos vasos sangüíneos que atravessam determinados tecidos para onde seletivamente conseguem migrar.

A caracterização e reconhecimento de genes envolvidos no reconhecimento, reparo ou programação da morte celular de células anômalas; de genes envolvidos no controle imunológico de reconhecimento e reparo/destruição das células danificadas; de genes capazes de interferir na capacidade de multiplicação à distância (p.ex. o gene nm23); de invadir tecidos circunjacentes (p.ex. o gene da sialoproteína, o gene da mucina, da galectina-3, etc); de fatores angiogênicos capazes de prover aporte nutricional a estas células de crescimento acelerado (p.ex. o gene $V E G F)$ e de vários outros fundamentais para a progressão de um clone tumoral primário para fenótipos mais agressivos com invasão e metastatização à distância permite reconhecimento destes diferentes fenótipos auxiliando no diagnóstico e caracterização de padrões diferentes de comportamento tumoral (26).

$\mathrm{O}$ acúmulo de anormalidades vantajosas para células tumorais durante seu processo de desenvolvimento e progressão foi mais extensa e detalhadamente descrito no câncer de cólon (27). Neste tumor, quando o gene supressor tumoral APC é inativado, pode ocorrer proliferação da mucosa epitelial normal de forma anômala formando um pequeno pólipo. Mutações em oncogenes como $K$-ras, ou em outros genes supressores tumorais como $p 53$ e DCC ocorrem sucessivamente a seguir transformando este pólipo em um adenoma maior a partir do qual aparecerá em seguida o carcinoma. Em indivíduos que têm genes reconhecedores e reparadores de defeitos no DNA (mismatch-repair genes) inativados ou não-funcionantes, a prevalência destas mutações é acelerada. O gene $A P C$ foi descrito como o guardião do epitélio colônico e existem fortes evidências de que alterações em $A P C$ sejam os eventos iniciadores do processo neoplásico. Entretanto, em outros tumores, a perda ou inativação de genes supressores tumorais provavelmente seja um fenômeno final ou muito tardio do processo de carcinogênese (28).

\section{INSTABILIDADE GENÔMICA}

Instabilidade do genoma tem sido considerada como importante fator na formação e progressão da neoplasia. Como vimos, para se tornar neoplásica, a célula deve sofrer uma, ou mais de uma, alteração no seu genoma, usualmente na forma de mutações nos genes envolvidos no ciclo celular, o que leva a um relaxamento dos mecanismos de controle do crescimento e divisão. Células nas quais os mecanismos de controle foram alterados têm maior chance de desenvolver novas anormalidades genéticas, isto é, se tornam instáveis.

Quando a célula sofre grandes danos, que sobrepujam a sua capacidade de reparação, torna-se sujeita a sofrer alterações grosseiras, como translocações, perdas de material cromossômico, amplificações, duplicações ou inversões de genes, substituição de pares de bases. Na seqüência codificadora, inserções, deleções, duplicações e inversões geralmente resultam na 
produção de produtos gênicos truncados, ou encurtados, enquanto que as trocas de bases alteram a seqüência de aminoácidos do produto gênico ou também resultam em produto truncado. Mutações externas à região codificadora podem afetar a transcrição, a tradução e o splicing do RNA mensageiro e seu processamento. Assim, existe uma relação entre o agente causador deste dano e o grau de heterogeneidade do clone celular que se desenvolverá, o que, por sua vez, guarda estreita relação com a capacidade de algumas destas células adquirirem resistência terapêutica e, portanto, definam pior prognóstico ao tumor (29). A variabilidade encontrada nas células tumorais é resultado da instabilidade genômica que usualmente ocorre no processo de tumorigênese. Estas anormalidades, quando grosseiras, são chamadas de instabilidade cromossômica e podem ser evidenciadas por estudos citogenéticos, corando-se o cromossoma com compostos fluorescentes (FISH), por hibridização genômica comparativa (CGH) ou por métodos baseados na comparação entre seqüências normais e tumorais amplificadas por PCR (reação em cadeia da polimerase). Estudos baseados na perda de heterozigose $(\mathrm{LOH})$, isto é, na perda de segmentos cromossômicos em tecidos tumorais em relação ao tecido normal de fragmentos repetitivos de seqüências espalhadas pelo nosso genoma, chamadas microssatélites, têm permitido identificar uma série de genes supressores importantes como o $p 53, A P C, D P C 4$ e $p 16$, no processo carcinogênico de diversos tecidos (29).

\section{ALTERAÇÕES EPIGENÉTICAS}

Embora menos compreendidas, alterações epigenéticas também devem ser importantes no processo de tumorigênese. Alterações epigenéticas são anormalidades hereditárias da função gênica que são mediadas por outros fatores que não as alterações que ocorrem primariamente na seqüência do DNA. Um exemplo é a metilação do DNA na região promotora, um fenômeno que pode alterar a expressão de um determinado gene. Genes que são ativamente transcritos tendem a ter baixos níveis de metilação das suas regiões promotoras enquanto que genes silenciosos, isto é, que não se expressam em determinados tecidos ou circunstâncias, têm sua região promotora altamente metilada $(30,31)$. Existem evidências de que a metilação do DNA pode ser um mecanismo não-mutacional pelo qual a função de genes supressores tumorais fica desregulada, predispondo à perda de função do segundo alelo protetor, como Knudson preconizou em sua teoria dos dois golpes $(20,30,31)$. Anormalidades de metilação também podem levar a aumento na expressão de proto-oncogenes aumentando a freqüência de mutações e a instabilidade genômica (31). Outra alteração epigenética é o imprinting genômico, uma modificação do DNA reversível que causa expressão diferente de genes homólogos herdados da mãe ou do pai (30-32). A perda do imprinting fisiológico faz com que genes que não deveriam estar normalmente expressos possam estar ativados produzindo substâncias vantajosas para o crescimento celular ou, ao contrário, genes supressores tumorais que deveriam ser normalmente transcritos sejam silenciados, permitindo a progressão de ciclo celular anormal $(31,32)$.

\section{PERSPECTIVAS DIAGNÓSTICAS E TERAPÊUTICAS}

A possibilidade de identificar células neoplásicas usando técnicas de genética molecular foi inicialmente demonstrada por Sidransky e cols. em 1991, através da detecção de células em urina de pacientes com câncer de bexiga que tinham uma mutação de p53 similar à detectada nas células do tumor primário (33). Desde então, sucederam-se inúmeros estudos mostrando detecção de câncer através de pesquisa em plasma, saliva, fezes, líquido peritoneal e virtualmente qualquer amostra de secreção ou tecido humano, delineando-se um painel crescente de marcadores moleculares de diagnóstico e detecção precoce (34). De forma similar, temos marcadores moleculares capazes de proporcionar detecção precoce, numa fase pré-clínica de doença ou mesmo antes de seu aparecimento. A própria mutação de $p 53 \mathrm{em}$ células coletadas na urina pode aparecer anos antes do câncer de bexiga (35). De forma similar, mutação no gene $K$-ras detectada em suco pancreático pode preceder o adenocarcinoma pancreático e mutações oncogênicas em lavados colônicos podem predizer risco para câncer de cólon (30). A identificação de mutações pode determinar uma vigilância maior com detecção mais precoce e conseqüente melhor prognóstico para alguns tipos de tumores, como os genes BRCAI e BRCA2 que identificam pacientes de risco para os cânceres de mama e ovário (36). Talvez o mais importante exemplo de como tal previsão de risco de malignidade pode causar impacto no prognóstico de um indivíduo seja a mutação do gene ret. A identificação de mutações permite identificar indivíduos de risco para desenvolvimento de carcinoma medular da tiróide (37). Estes indivíduos podem ser tiroidectomizados e jamais virem 
a apresentar este tipo de câncer agressivo e potencialmente letal (10).

Não apenas identificamos grupos de risco para câncer, como, traçando o perfil genético de um determinado tumor, podemos classificá-lo e delinear diferentes estratégias de tratamento. Assim, o câncer de mama pode ser dividido em subtipos com base nas características moleculares de suas células. Cada um destes subtipos tem propriedades diferentes, comportamento clínico diferente e características de sobrevida diferentes (38).

A decorrência natural da genética molecular é o desenvolvimento de inúmeras drogas, como o STI571 , recentemente aprovado pelo FDA, que poderá revolucionar o tratamento da leucemia mielóide crônica. Este inibidor de tirosina-quinase talvez também possa bloquear outros cânceres onde esta via de sinalização está ativada (39). Outros alvos moleculares para terapia gênica, como o $c$-kit e PDGFR, estão em fases avançadas de testes.

Compreendendo o mecanismo de ação dos genes envolvidos na tumorigênese em breve poderemos desativar oncogenes inadequadamente ativados, reintroduzir GST defeituosos, induzir as células mutadas a sofrer apoptose, impedir proliferação e metastatizacão à distância etc. Experimentos in vitro e in vivo sugerem que a reintrodução de um cromossoma, do segmento ou do gene perdido pode reverter a célula maligna ao seu fenótipo normal. Por exemplo, a reintrodução do cromossoma 11 e do cromossoma 6 intactos em células tumorais de cultura abole completamente a capacidade destas células produzirem tumores em camundongos (40). De forma similar, a introdução de gene intacto do $R B$ em linhagens celulares derivadas de retinoblastoma e de osteossarcoma resulta em supressão do fenótipo neoplásico (41). A possibilidade de aplicar tal tipo de estratégia abre novas perspectivas no tratamento do câncer humano. De fato, centenas de projetos, alguns em fase 2 ou 3 de experimentação, estão sendo desenvolvidos por várias empresas pelo mundo. Podemos prever que, em breve, a terapia do câncer será dirigida para a correção dos defeitos genéticos envolvidos, reintroduzindo genes supressores tumorais perdidos, bloqueando os oncogenes erroneamente ativados, restaurando a apoptose ou restaurando o equilíbrio genômico. Já se demonstrou tanto in vitro como in vivo que o tratamento com inibidores da DNA metiltransferase e histona deacetilase pode reverter danos na metilação do DNA e diminuir os fenômenos epigenéticos (32). Alternativamente, genes "suicidas" carregando potentes quimioterápicos, terapia imunogenética visando aumentar antigenicidade da célula tumoral, introdução de genes virais nas células tumorais para matá-las e muitas outras estratégias deverão estar ao nosso alcance.

\section{REFERÊNCIAS}

1. Boyle P. Global burden of cancer. Lancet 1997;349 (Suppl 2):23-6

2. C.10 Taxa de mortalidade específica por neoplasias malignas em 1999. http://tabnet.datasus.gov.br/cgi/ tabcgi.exe?idb2001/c10.def

3. News from the $\mathrm{NCl}$. http://newscenter.cancer.gov/ pressreleases/reportnation.html

4. Fidler IJ. Molecular biology of cancer: invasion and metastasis. In DeVita VT, Hellman S, Rosemberg AS (eds). Cancer: principles \& practice of oncology. LipincottRaven Publishers, Philadelphia 1997; 135-52.

5. Trichopoulos D, Li FP, Hunter DJ. What causes cancer? Sci Am 1996;275:80-7.

6. Kim JW, Lee CG, Han SM, Kim KS, Kim JO, Lee JM et al. Loss of heterozygosity of the retinoblastoma and p53 genes in primary cervical carcinomas with human papillomavirus infection. Gynecol Oncol 1997;67:215-21.

7. zur Hausen H. Cervical carcinoma and human papillomavirus: on the road to preventing a major human cancer. J Natl Cancer Inst 2001;93:252-3.

8. Vousden $\mathrm{KH}$, Farrell PJ. Viruses and human cancer. $\mathbf{B r}$ Med Bull 1994;50;560-81.

9. Morari EC, Leite JLP, Granja F, Assumpção LVM, Ward LS. The null genotype of glutathione s-transferase $\mathrm{Ml}$ and $\mathrm{T} 1$ locus increases the risk for thyroid cancer. Cancer Epidemiol. Biomarkers Prev - in press.

10. Giuffrida D, Ferrau F, Bordonaro R, Mattina M, Priolo D, Aiello RA et al. Medullary carcinoma of the thyroid: diagnosis and therapy. Clin Ter 2000; 151:29-35.

11. Parma J, Duprez L, Van Sande J, Hermans J, Rocentímetrosans $P$, VanVliet $G$ et al. Diversity and prevalence of somatic mutations in the thyrotropin receptor and $G$ s alpha genes as a cause of toxic thyroid adenomas. J Clin Endocrinol Metab 1997;82:2695-701.

12. Liu G, Duranteau L, Carel JC, Monroe J, Doyle DA, Shenker A. Leydig-cell tumors caused by an activating mutation of the gene encoding the luteinizing hormone receptor. N Engl J Med 1999;241:1731-6.

13. Latronico AC, Pinto EM, Domenice S, Fragoso MC, Martin RM, Zerbini $\mathrm{MC}$ et al. An inherited mutation outside the highly conserved DNA-binding domain of the p53 tumor suppressor protein in children and adults with sporadic adrenocortical tumors. J Clin Endocrinol Metab 2001:86:4970-3.

14. Ribeiro RC, Sandrini F, Figueiredo B, Zambetti GP, Michalkiewicz E, Lafferty AR et al. An inherited p53 mutation that contributes in a tissue-specific manner to pediatric adrenal cortical carcinoma. Proc Natl Acad Sci USA 2001:98:9330-5.

15. Fearon ER. Human cancer syndromes: clues to the origin and nature of cancer. Science 1997;278:1043-58. 
16. Paulovich AG, Toczyski DP, Hartwell LH. When checkpoints fail. Cell 1997;83:315-21.

17. Ward LS. Molecular basis for the diagnosis and therapy of the thyroid cancer. Rev Bras Clin Terap 2000;26: 103-7.

18. Nowell PC, Jensen J, Gardner F. Two complex translocations in chronic granulocytic leukemia involving chromosomes 22, 9 and a third chromosome. Humangenetik $1975 ; 30: 13-21$

19. Weinberg R. Oncogenes, antioncogenes, and the molecular bases of multistep carcinogenesis. Cancer Res 1989:49:3713-21.

20. Knudson AG. Antioncogenes and human cancer. Proc Nat Acad Sci USA 1993;90:10914-21.

21. Livingstone DM, Shivdasani R. Toward mechanismbased cancer care. JAMA 2001;285:588-93.

22. Horvitz HR. Genetic control of programmed cell death in nematode Caenorhabditis elegans. Cancer Res 1999:59:1701s-6s.

23. Cooke HJ, Smith BA. Variability at the telomeres of the human $X / Y$ pseudoautosomal region. Cold Spring Harb Symp Quant Biol 1986;51:213-9.

24. im NW, Piatyszek MA, Prowse KR, Harley CB, West MD, Ho $\mathrm{PL}$ et al. Specific association of human telomerase activity with immortal cells and cancer. Science 1994;266:2011-5.

25. de Lange T. Protection of mammalian telomeres. Oncogene 2002;21:532-40.

26. Ruoslahti E. How cancer spreads. Sci Am 1996;275:72-7.

27. Kinzler KW, Vogelstein B. Lessons from hereditary colorectal cancer. Cell 1996;87:159-70.

28. Ward LS, Fagin JA. Molecular genetics of thyroid cancer: evidence that inactivation of tumor suppressor genes occurs at late stages of tumor progression. In: S. Handwerger. Molecular and cellular pediatric endocrinology. Totowa, NJ, Humana Press Inc, 1998;201-11.

29. Fagin JA. Minireview: branded from the start-distinct oncogenic initiating events may determine tumor fate in the thyroid. Mol Endocrinol 2002; 16:903-11.

30. Pharoah P, Caldas C. Molecular genetics and the assessment of human cancers. Expert Reviews Mol Med 1999. http://www-ermm.cbcu.cam.ac.uk.

31. Plass C, Soloway PD. DNA methylation, imprinting and cancer. Eur J Hum Genet 2002; 10:6-16.
32. Schofield PN, Joyce JA, Lam WK, Grandjean V, Ferguson-Smith A, Reik W et al. Genomic imprinting and cancer; new paradigms in the genetics of neoplasia. Toxicol Lett 2001;120:151-60.

33. Sidransky D, Von Eschenbach A, Tsai YC, Jones P, Summerhayes I, Marshall F et al. Identification of p53 gene mutations in bladder cancers and urine samples. Science 1991:252:706-9.

34. Sidransky D. Emerging molecular markers of cancer. Nature Rev Cancer 2002:2:210-9.

35. Hruban RH, van der Riet $P$, Erozan YS, Sidransky D. Brief report: molecular biology and the early detection of carcinoma of the bladder - the case of Hubert $\mathrm{H}$. Humphrey. N Engl J Med 1994;330:1276-8.

36. Olivotto IA, Gomi A, Bancej C, Brisson J, Tonita J, Kan L et al. Influence of delay to diagnosis on prognostic indicators of screen-detected breast carcinoma. Cancer 2002; $94: 2143-50$

37. Neumann HP, Eng C, Mulligan LM, Glavac D, Zauner I, Ponder BA et al. Consequences of direct genetic testing for germline mutations in the clinical management of families with multiple endocrine neoplasia, Type II. JAMA 1995;274:1149-51

38. Guerra E, Alberti S. Molecular prognostic indicators for breast cancer. Tumori 2001;87:\$23-5.

39. Habeck M. FDA licences imatinib mesylate for CML. Lancet Oncol 2002;3:6.

40. Weissman BE, Saxon PJ, Pasquale SR, Jones GR, Geiser $A G$, Stambride EJ. Introduction of a normal chromosome 11 into a Wilm's tumor cell line controls its tumorigenic expression. Science 1987;236:175-80.

41. Huang H-JS, Yee J-K, Shew J-Y et al. Suppression of the neoplastic phenotype by replacement of the RB gene in human cancer cells. Science 1988;242:1563-6.

\section{Endereço para correspondência:}

Laura Sterian Ward

GEMOCA, Med. Interna, Clínica Médica - FCM

Rua Tessália Vieira de Camargo 161

13081-970 Campinas, SP

F/FAX: (019) 289-4107

e.mail: ward@unicamp.br 